\title{
Reclassification of Streptomyces hygroscopicus strains as Streptomyces aldersoniae sp. nov., Streptomyces angustmyceticus sp. nov., comb. nov., Streptomyces ascomycinicus sp. nov., Streptomyces decoyicus sp. nov., comb. nov., Streptomyces milbemycinicus sp. nov. and Streptomyces wellingtoniae sp. nov.
}

\author{
Yashawant Kumar and Michael Goodfellow
}

Correspondence

Michael Goodfellow

m.goodfellow@ncl.ac.uk
School of Biology, University of Newcastle, Newcastle upon Tyne, NE1 7RU, UK
The taxonomy of the genus Streptomyces has been clarified and extended by the application of genotypic and phenotypic procedures to representatives of formally described and putatively novel species (Manfio et al., 1995, 2003; Lanoot et al., 2002, 2004). 16S rRNA gene sequence data show that the type strains of many Streptomyces species can be assigned to multimembered species groups, as exemplified by species classified in the Streptomyces albidoflavus (Lanoot et al., 2005), Streptomyces griseus (Liu et al., 2005), Streptomyces violaceoruber (Duangmal et al., 2005), Streptomyces violaceusniger (Goodfellow et al., 2007) and Streptomyces yeochonensis (Xu et al., 2006) clades. The $S$. violaceusniger clade encompasses strains that produce a grey aerial spore mass and a greyish-yellow substrate mycelium on oatmeal agar, form aerial hyphae that differentiate into spiral chains of rugose-ornamented spores (Sembiring et al.,

The GenBank/EMBL/DDBJ accession numbers for the $16 \mathrm{~S}$ rRNA gene sequences of the tested strains are EU170123 (S. aldersoniae NRRL $\left.18513^{\top}\right)$, EU170119 (S. angustmyceticus NRRL B-2347 $\left.{ }^{\top}\right)$, EU170121 (S. ascomycinicus DSM 40822 ${ }^{\top}$ ), EU170127 (S. decoyicus NRRL $2666^{\top}$ ), EU170126 (S. milbemycinicus NRRL 5739 ${ }^{\top}$ ) and EU170124 (S. wellingtoniae DSM $40632^{\mathrm{T}}$ ).
2000; Goodfellow et al., 2007; Kumar \& Goodfellow, 2008), show the same pattern of HPLC-detected metabolites, namely elaiophylin, geldanamycin, nigericin and an uncharacterized polyene (Ward \& Goodfellow, 2004), and give a characteristic amplification product with taxon-specific primers (Kumar et al., 2007).

The $S$. violaceusniger $16 \mathrm{~S}$ rRNA gene clade currently contains 22 species with validly published names (Kumar \& Goodfellow, 2008), delineated mainly by using a combination of DNA-DNA relatedness and standard phenotypic data (Sembiring et al., 2000; Goodfellow et al., 2007). The taxon includes two well-known species, Streptomyces hygroscopicus and S. violaceusniger, which have been considered to be particularly rich sources of novel antibiotics (Strohl, 2004). However, some strains labelled S. hygroscopicus have been misclassified, as they belong to novel species classified within and outside the S. violaceusniger clade (Goodfellow et al., 2007; Kumar \& Goodfellow, 2008). It is important to classify Streptomyces strains correctly, not least to determine the extent to which streptomycete taxonomy can be used as a surrogate for chemical diversity and hence influence bioprospecting strategies (Bull et al., 2005). 
The present study was designed to clarify further the taxonomic standing of strains classified as S. hygroscopicus. To this end, S. hygroscopicus NRRL 18513 (Yao \& Hamill, 1993), S. hygroscopicus subsp. angustmyceticus NRRL B-2347 (Yüntsen et al., 1956), 'S. hygroscopicus subsp. aureolacrimosus' NRRL 5739 (Haber et al., 1991), S. hygroscopicus subsp. decoyicus NRRL $2666^{\mathrm{T}}$ (Vavra et al., 1959), S. hygroscopicus subsp. glebosus NRRL B-3248 ${ }^{\mathrm{T}}$ (Ohmori et al., 1962), S. hygroscopicus subsp. hygroscopicus DSM 40632 (Tresner \& Backus, 1956) and S. hygroscopicus subsp. hygroscopicus DSM 40822 (Hütter, 1967) were the subject of a polyphasic taxonomic study. The resultant data show that the eight strains form distinct centres of taxonomic variation in the genus Streptomyces that can be equated with species, albeit ones that fall outside the S. violaceusniger $16 \mathrm{~S}$ rRNA gene clade.

The strains were maintained on oatmeal agar (DSMZ, 1998) slopes at $4{ }^{\circ} \mathrm{C}$ and as mycelial fragments and spores in glycerol $(20 \%, \mathrm{v} / \mathrm{v})$ at $-20{ }^{\circ} \mathrm{C}$. Biomass for $16 \mathrm{~S}$ rRNA gene sequencing was prepared by growing the organisms in shake flasks of tryptic soy broth at 160 r.p.m. for 7 days at $28{ }^{\circ} \mathrm{C}$ prior to harvesting by centrifugation.

Genomic DNA extraction, PCR amplification and sequencing of 16S rRNA genes from the strains was carried out with minor modifications (Kumar et al., 2007) of the procedure described by Goodfellow et al. (2007). The resultant sequence data were aligned using the PHYDIT program (available at http://plaza.snu.ac.kr/ jchun/phydit/) and the alignments were checked manually. Using the sequence data, a BLAST search (Altschul et al., 1997) of GenBank was performed to detect the closest relatives of each of the strains; the sequences included those of representatives of the S. violaceusniger clade. Phylogenetic trees were inferred using four tree-making algorithms (least-squares, maximumlikelihood, maximum-parsimony and neighbour-joining) drawn from the PHYLIP 3.5c suite of programs (Felsenstein, 1993). Evolutionary distance matrices were prepared for the least-squares and neighbour-joining methods, as described by Jukes \& Cantor (1969). A bootstrap analysis was performed (Felsenstein, 1985) with 1000 resamplings of the neighbour-joining dataset by using the SEQBOOT and CONSENSE programs from the PHYLIP package. Almost-complete $16 \mathrm{~S}$ rRNA gene sequences (1441-1450 nt) were obtained for the strains. It can be seen from Fig. 1 that none of the strains were closely related to members of the $S$. violaceusniger $16 \mathrm{~S}$ rRNA clade, including the type strain of $S$. hygroscopicus, or with any of their closest phylogenetic neighbours.

The strains were examined for their ability to produce pigments on oatmeal and peptone-yeast extract-iron agars, and for spore-chain morphology and spore-surface ornamentation using previously described procedures (Shirling \& Gottlieb, 1966; Sembiring et al., 2000; Goodfellow et al., 2007). They were also examined for their ability to grow on modified Bennett's, glucose-yeast extract-malt extract, glycerol-asparagine, inorganic salts-starch, tyrosine and yeast extract-malt-extract agars and for the presence of LLdiaminopimelic acid (LL- $\mathrm{A}_{2} \mathrm{pm}$ ) in whole-organism hydrolysates after Staneck \& Roberts (1974) and probed using the $S$. violaceusniger clade-specific primers, as described by Kumar et al. (2007). The strains grew well on glucose-yeast extract-malt extract, glycerol-asparagine, tyrosine and yeast extract-malt extract agars, and produced whole-organism

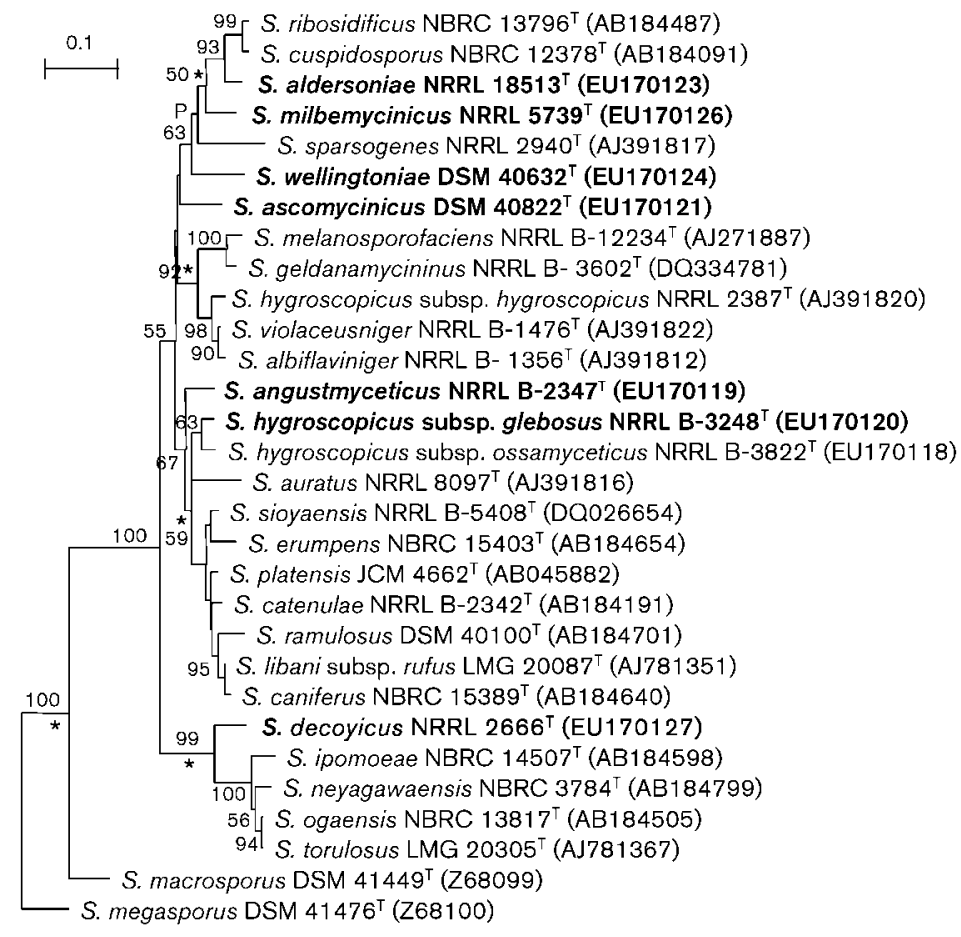

Fig. 1. Neighbour-joining tree (Saitou \& Nei, 1987) showing relationships between the tested strains and between them, representatives of the Streptomyces violaceusniger 16S rRNA gene clade and phylogenetically close Streptomyces strains based on almost-complete 16S rRNA gene sequences. Asterisks denote branches that were also recovered using the least-squares (Fitch \& Margoliash, 1967), maximum-likelihood (Felsenstein, 1981) and maximum-parsimony (Kluge \& Farris, 1969) tree-making algorithms. $P$ indicates branches that were recovered using the maximum-parsimony method. Bar, 0.1 substitutions per site. Numbers at nodes indicate levels of bootstrap support (\%) based on neighbour-joining analysis of 1000 resampled datasets. The tested strains are given in bold. GenBank accession numbers are given in parentheses. 
hydrolysates rich in LL- $\mathrm{A}_{2} \mathrm{pm}$. They did not form a grey aerial spore mass on oatmeal agar and produced neither spiral chains of rugose-ornamented spores nor the diagnostic PCR amplification product with the clade-specific primers. These results indicate that the organisms have properties consistent with their assignment to the genus Streptomyces, but not with their inclusion in the S. violaceusniger 16S rRNA gene clade (Manfio et al., 1995; Kumar \& Goodfellow, 2008).

The six organisms and the type strains of Streptomyces cuspidosporus and Streptomyces torulosus were examined for a range of phenotypic properties known to be of value in streptomycete systematics (Atalan et al., 2000; Xu et al., 2006; Goodfellow et al., 2007). To this end, they were examined for phenotypic properties using media and methods described by Williams et al. (1983). The chemical and morphological properties of the organisms were consistent with their classification in the genus Streptomyces. All of the strains hydrolysed aesculin and arbutin and used L-arginine as a sole source of carbon and nitrogen, but not aminobutyric acid, DL-aspartic acid, DL-norleucine or Lnorvaline. The assignment of the strains to the genus Streptomyces is in line with the $16 \mathrm{~S}$ rRNA gene sequence data.

The strains formed well-delineated phyletic lines in the Streptomyces 16S rRNA gene tree (Fig. 1). Four of the strains, namely S. hygroscopicus NRRL 18513, 'S. hygroscopicus subsp. aureolacrimosus' NRRL 5739 and S. hygroscopicus subsp. hygroscopicus strains DSM 40632 and DSM 40822 , belong to or are most closely associated with members of the S. cuspidosporus clade, sharing their highest $16 \mathrm{~S}$ rRNA gene similarities with the type strain of $S$. cuspidosporus (97.6-99.0\%, values which correspond to between 17 and $35 \mathrm{nt}$ differences). The closest relationship found between the four tested strains was that between $S$. hygroscopicus NRRL 18513 and 'S. hygroscopicus subsp. aureolacrimosus' NRRL 5739; these organisms shared a 16S rRNA gene sequence similarity of $98.6 \%$, a value that corresponds to $22 \mathrm{nt}$ differences over 1444 locations. In contrast, the most distantly related organisms, S. hygroscopicus NRRL 18513 and S. hygroscopicus subsp. hygroscopicus DSM 40822, shared a 16S rRNA gene sequence similarity of $97.6 \%$ (35 nt differences over 1449 locations). In addition, S. hygroscopicus NRRL 18513 was relatively closely related to the type strain of Streptomyces ribosidificus: these organisms shared a 16S rRNA gene sequence similarity of $99.0 \%$ (14 nt differences over 1444 positions). DNADNA relatedness studies were not carried out between the four tested strains or between them and the type strains of $S$. cuspidosporus and S. ribosidificus as the respective $16 \mathrm{~S}$ rRNA gene similarity values are well below the $99.4 \%$ level at which Streptomyces strains have been shown to belong to different genomic species (Liu et al., 2005; Xu et al., 2006; Goodfellow et al., 2007; Sun et al., 2007).

The four strains assigned to the $S$. cuspidosporus clade can be distinguished from one another and from the type strain of S. cuspidosporus, their nearest phylogenetic neighbour, using a range of phenotypic properties (Table 1). The excellent congruence found between the 16S rRNA gene sequence and phenotypic data is consistent with the classification of all four strains within novel Streptomyces species. It is, therefore, proposed that $S$. hygroscopicus NRRL 18513, 'S. hygroscopicus subsp. aureolacrimosus' NRRL 5739 and S. hygroscopicus subsp. hygroscopicus strains DSM 40632 and DSM 40822 be classified as the type strains of Streptomyces aldersoniae sp. nov., Streptomyces milbemycinicus sp. nov., Streptomyces wellingtoniae sp. nov. and Streptomyces ascomycinicus sp. nov., respectively.

S. hygroscopicus subsp. decoyicus NRRL $2666^{\mathrm{T}}$ is loosely associated with the Streptomyces ipomoeae 16S rRNA gene clade (Fig. 1); it shows its highest $16 \mathrm{~S}$ rRNA gene similarity to the type strains of Streptomyces ogaensis and S. torulosus. However, these three strains share relatively low $16 \mathrm{~S}$ rRNA gene similarity of $98.4 \%$, a value which corresponds to 23 nt differences over 1443 positions. These strains can also be distinguished using a combination of phenotypic features (Table 1). The genotypic and phenotypic data show that strain NRRL $2666^{\mathrm{T}}$ should be classified in the genus Streptomyces within a distinct species. The strain has to be named after the subspecific epithet in accordance with Rule 50a of the International Code of Nomenclature of Bacteria (Lapage et al., 1992); although the epithet decoyicus is incorrectly formed and should be decoyininicus, such corrections are no longer permitted according to Rule 61 (De Vos \& Trüper, 2000). Consequently, Streptomyces hygroscopicus subsp. decoyicus NRRL $2666^{\mathrm{T}}$ should be designated the type strain of Streptomyces decoyicus (Vavra et al., 1959) sp. nov., comb. nov.

As shown in Fig. 1, S. hygroscopicus subsp. angustmyceticus NRRL B $-2347^{\mathrm{T}}$ is closely related to $S$. hygroscopicus subsp. glebosus NRRL B-3248 ${ }^{\mathrm{T}}$. These organisms share a $16 \mathrm{~S}$ rRNA gene sequence similarity of $99.0 \%$ (15 nt differences over 1447 locations) and can be separated readily using a range of phenotypic properties (Table 1). Consequently, it is proposed that Streptomyces hygroscopicus subsp. angustmyceticus NRRL B- $2347^{\mathrm{T}}$ be classified as the type strain of Streptomyces angustmyceticus (Yüntsen et al. 1956) comb. nov., sp. nov. by following Rule 50a of the International Code of Nomenclature of Bacteria (Lapage et al., 1992). Correction of the epithet to angustmycinicus is not permitted under Rule 61 (De Vos \& Trüper, 2000).

This study provides further evidence that the genus Streptomyces is underspeciated (Manfio et al., 2003; Xu et al., 2006; Goodfellow et al., 2007), despite the large number of species it contains (http://www.bacterio.cict.fr/ index.html).

\section{Description of Streptomyces aldersoniae sp. nov.}

Streptomyces aldersoniae (al.der.so'ni.ae. N.L. fem. gen. n. aldersoniae of Alderson, named in honour of Grace Alderson for her contributions to actinomycete systematics). 
Table 1. Phenotypic properties that separate the tested S. hygroscopicus strains from one another and from phylogenetically close neighbours

Strains: 1, S. hygroscopicus subsp. glebosus NRRL B-3248 ${ }^{\mathrm{T}}$; 2, S. cuspidosporus NBRC $12379^{\mathrm{T}}$; 3, S. hygroscopicus NRRL 18513; 4, 'S. hygroscopicus subsp. aureolacrimosus' NRRL 5739; 5, S. hygroscopicus subsp. hygroscopicus DSM 40822; 6, S. hygroscopicus subsp. hygroscopicus DSM 40632; 7, S. torulosus LMG $20305^{\mathrm{T}}$; 8, S. hygroscopicus subsp. decoyicus NRRL 2666 ; 9, S. hygroscopicus subsp. angustmyceticus NRRL B-2347 ${ }^{\mathrm{T}}$. Data were generated in this study. All the strains degraded adenine, grew on gelatin, used D-glucose, glycerol, maltose, D-mannose, sucrose and trehalose as sole carbon sources and were susceptible to ampicillin, cefoxitin, cephalosporin (all at $32 \mu \mathrm{g} \mathrm{ml}^{-1}$ ) and fusidic acid (at $8 \mu \mathrm{g} \mathrm{ml}{ }^{-1}$ ). They were negative for allantoin hydrolysis, did not degrade cellulose, keratin, pectin, tributyrin, xanthine or xylan and did not use D-arabinose, amygdalin, arbutin, citric acid, dulcitol, inulin, pectin, propanol, pyruvic acid or L-sorbose as sole carbon sources.

\begin{tabular}{|c|c|c|c|c|c|c|c|c|c|}
\hline Characteristic & 1 & 2 & 3 & 4 & 5 & 6 & 7 & 8 & 9 \\
\hline \multicolumn{10}{|c|}{ Morphology and pigmentation on oatmeal agar } \\
\hline Aerial spore mass colour & $\begin{array}{l}\text { Yellowish } \\
\text { grey }\end{array}$ & Grey & $\begin{array}{l}\text { Whitish grey, } \\
\text { becoming } \\
\text { black and } \\
\text { moist }\end{array}$ & Grey & $\begin{array}{l}\text { Dark } \\
\text { grey }\end{array}$ & $\begin{array}{l}\text { Reddish } \\
\text { grey }\end{array}$ & Grey & $\begin{array}{l}\text { Grey, } \\
\text { becoming } \\
\text { black and } \\
\text { moist }\end{array}$ & $\begin{array}{l}\text { Greyish } \\
\text { white }\end{array}$ \\
\hline Substrate mycelium colour & $\begin{array}{c}\text { Yellowish } \\
\text { brown }\end{array}$ & $\begin{array}{r}\text { Greyish } \\
\text { yellow }\end{array}$ & Orange & Olive grey & $\begin{array}{l}\text { Yellowish } \\
\text { brown }\end{array}$ & $\begin{array}{c}\text { Reddish } \\
\text { purple }\end{array}$ & $\begin{array}{c}\text { Yellowish } \\
\text { brown }\end{array}$ & $\begin{array}{l}\text { Deep } \\
\text { yellow }\end{array}$ & $\begin{array}{l}\text { Deep } \\
\text { yellow }\end{array}$ \\
\hline Diffusible pigment & $\begin{array}{l}\text { Orange- } \\
\text { yellow }\end{array}$ & None & None & Pale olive & Orange & $\begin{array}{c}\text { Reddish } \\
\text { purple }\end{array}$ & None & None & None \\
\hline Spore chains & Spirals & $\begin{array}{l}\text { Loops } \\
\text { or } \\
\text { spirals }\end{array}$ & Loops & $\begin{array}{l}\text { Loops or } \\
\text { spirals }\end{array}$ & $\begin{array}{l}\text { Loops or } \\
\text { spirals }\end{array}$ & $\begin{array}{l}\text { Loops or } \\
\text { spirals }\end{array}$ & Spirals & Spirals & Spirals \\
\hline Spore ornamentation & Smooth & Spiny & Smooth & Warty & Spiny & Smooth & Knobbly & Smooth & Smooth \\
\hline Production of melanin pigments & - & - & - & - & - & - & + & - & - \\
\hline \multicolumn{10}{|l|}{ Degradation tests $(\%, \mathrm{w} / \mathrm{v})$} \\
\hline Casein $(1 \%)$ & + & + & + & - & + & + & + & + & - \\
\hline Hypoxanthine $(0.4 \%)$ & + & - & - & - & - & + & - & + & + \\
\hline Starch $(1 \%)$ & + & + & + & + & + & - & + & - & - \\
\hline Tyrosine $(0.5 \%)$ & + & - & - & + & + & + & + & + & + \\
\hline Uric acid $(0.5 \%)$ & + & - & - & - & - & + & - & + & + \\
\hline \multicolumn{10}{|l|}{ Growth on sole carbon sources } \\
\hline \multicolumn{10}{|l|}{ At $1 \%(\mathrm{w} / \mathrm{v})$} \\
\hline Adonitol & - & - & + & - & - & - & + & - & - \\
\hline L-Arabinose & - & + & + & + & + & + & + & - & - \\
\hline D-Arabitol & + & + & - & - & + & + & + & + & + \\
\hline Cellobiose & + & + & + & - & + & + & - & + & + \\
\hline Dextrin & + & - & + & - & + & + & - & + & + \\
\hline meso-Erythritol & - & - & + & - & + & + & - & - & - \\
\hline D-Fructose & + & + & + & - & + & + & + & + & + \\
\hline L-Fucose & - & - & - & - & + & - & - & + & - \\
\hline D-Galactose & + & + & + & - & + & + & + & + & + \\
\hline Glycogen & + & + & + & - & + & + & - & + & + \\
\hline myo-Inositol & + & + & + & + & + & + & + & + & - \\
\hline$\alpha$-Lactose & + & + & - & - & + & + & - & - & - \\
\hline Melezitose & - & + & + & - & - & - & - & + & + \\
\hline L-Rhamnose & - & + & - & + & + & + & + & - & - \\
\hline D-Ribose & + & + & - & - & + & + & - & + & - \\
\hline Raffinose & + & + & + & - & + & + & + & - & + \\
\hline Salicin & + & + & + & - & + & - & - & - & - \\
\hline D-Sorbitol & + & - & - & - & - & - & + & - & + \\
\hline D-Xylose & + & + & + & + & + & + & + & + & - \\
\hline \multicolumn{10}{|l|}{ At $1 \%(\mathrm{v} / \mathrm{v})$} \\
\hline Butane-1,4-diol & + & - & - & - & + & + & - & + & + \\
\hline \multicolumn{10}{|c|}{ Growth on sole carbon and nitrogen sources at $1 \%(\mathrm{w} / \mathrm{v})$} \\
\hline L-Glutamic acid & + & + & + & - & + & + & + & + & + \\
\hline L-Leucine & + & + & + & - & - & + & + & + & + \\
\hline
\end{tabular}


Table 1. cont.

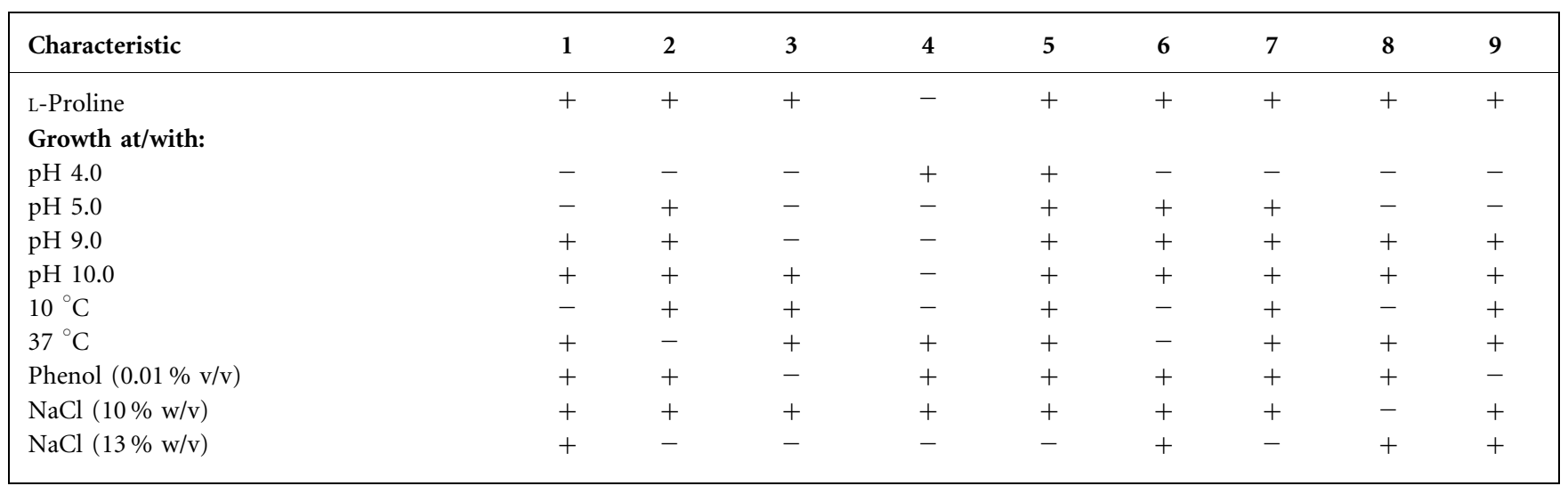

The description is based upon data taken from this and from a previous study (Yao \& Hamill, 1993). Spores $(0.8 \times 1.6 \mu \mathrm{m})$ are borne in loops with two to three turns. Spore surface smooth. Tween 60 is degraded. Does not use methanol or propanol as a sole carbon source (at $1 \%, \mathrm{v} / \mathrm{v})$. Sensitive to chlortetracycline hydrochloride $\left(64 \mu \mathrm{g} \mathrm{ml}^{-1}\right)$. Other phenotypic properties are mentioned in the text or in Table 1 . The $\mathrm{G}+\mathrm{C}$ content of the DNA of the type strain is $72.0 \mathrm{~mol} \%$. Produces the polyether antibiotic A80789, which shows antimicrobial activity against Gram-positive and anaerobic bacteria.

The type strain, DSM $41909^{\mathrm{T}}\left(=\mathrm{NRRL} 18513^{\mathrm{T}}\right)$, was isolated from soil collected in Manioka, New Guinea.

\section{Description of Streptomyces angustmyceticus (Yüntsen et al. 1956) sp. nov., comb. nov.}

Streptomyces angustmyceticus [an.gust.my.ce'ti.cus. N.L. n. angustmycinum angustmycin, an antibiotic; L. masc. suff. -icus adjectival suffix used with various meanings; N.L. masc. adj. angustmyceticus (sic) related to angustmycin, referring to the ability of the organism to produce angustmycin].

Basonym: Streptomyces hygroscopicus subsp. angustmyceticus Yüntsen et al. 1956.

The description is based upon data taken from this and from previous studies (Yüntsen et al., 1956; Dietz \& Mathews, 1962). Smooth, ornamented spores $(0.8 \times 1.6 \mu \mathrm{m})$ are borne in spirals with two to three turns. Degrades Tween 40 and uric acid. Does not use methanol or propanol as a sole carbon source (at $1 \%, \mathrm{v} / \mathrm{v}) . \alpha$-Alanine, L-alanine, L-arginine, L-glycine, L-histidine, L-isoleucine, L-ornithine, L-serine, Lthreonine and L-valine are used as sole nitrogen sources for energy and growth (at $1 \%, \mathrm{w} / \mathrm{v})$. Sensitive to doxycycline hydrochloride, gentamicin sulphate, kanamycin sulphate, neomycin sulphate, streptomycin sulphate and tobramycin sulphate (at $8 \mu \mathrm{g} \mathrm{ml}^{-1}$ ) and erythromycin, lincomycin hydrochloride, oleandomycin phosphate and rifampicin (at $32 \mu \mathrm{g} \mathrm{ml}^{-1}$ ). Other phenotypic properties are mentioned in the text or in Table 1. The G+C content of the DNA of the type strain is $70.2 \mathrm{~mol} \%$. Produces angustmycin A, B and C; the latter shows antitubercular activity.

The type strain is DSM $41683^{\mathrm{T}}\left(=\mathrm{NRRL} \mathrm{B}-2347^{\mathrm{T}}\right)$.

\section{Description of Streptomyces ascomycinicus sp. nov.}

Streptomyces ascomycinicus (as.co.my.ci'ni.cus. N.L. n. ascomycinum ascomycin, an antibiotic; L. masc. suffix -icus adjectival suffix used with various meanings; N.L. masc. adj. ascomycinicus related to ascomycin, referring to the ability of the organism to produce ascomycin).

The description is based upon data taken from this and from a previous study (Hütter, 1967). Rough spores with spiny surfaces are borne in loops $(0.5-0.7 \times 0.5-1.2 \mu \mathrm{m})$ with two to three turns. Grows well on modified Bennett's agar. Tweens 40, 60 and 80 are degraded. Does not use methanol or propanol as a sole carbon source (at $1 \%, \mathrm{v} / \mathrm{v})$. $\alpha$-Alanine and D-glycine are used as sole nitrogen sources for energy and growth (at $1 \%, \mathrm{w} / \mathrm{v})$. Sensitive to cephaloridine hydrochloride $\left(32 \mu \mathrm{g} \mathrm{ml}^{-1}\right)$, chlortetracycline hydrochloride $\left(64 \mu \mathrm{g} \mathrm{ml}^{-1}\right)$, erythromycin, gentamicin sulphate, kanamycin sulphate, lincomycin hydrochloride, neomycin sulphate and novobiocin $\left(4 \mu \mathrm{g} \mathrm{ml}^{-1}\right)$ and to doxycycline hydrochloride, oleandomycin phosphate, rifampicin, streptomycin sulphate, tetracycline hydrochloride and tobramycin sulphate $\left(8 \mu \mathrm{g} \mathrm{ml}^{-1}\right)$. Other phenotypic properties are mentioned in the text or in Table 1 . The $\mathrm{G}+\mathrm{C}$ content of the DNA of the type strain is $70.2 \mathrm{~mol} \%$. Produces ascomycin, which has an immunosuppressant action.

The type strain, DSM $40822^{\mathrm{T}}\left(=\mathrm{NBRC} 13981^{\mathrm{T}}\right)$, was isolated from soil collected in Sannomiya, Kobe City, Japan.

\section{Description of Streptomyces decoyicus (Vavra et al. 1959) sp. nov., comb. nov.}

Streptomyces decoyicus [de.co'yi.cus. N.L. n. decoyininum decoyinine, an antibiotic; L. masc. suff. -icus adjectival 
suffix used with various meanings; N.L. masc. adj. decoyicus (sic) related to decoyinine, referring to the ability of the organism to produce decoyinine].

Basonym: Streptomyces hygroscopicus subsp. decoyicus Vavra et al. 1959.

The description is based upon data taken from this and from previous studies (Vavra et al., 1959; Dietz \& Mathews, 1969). Spores $(0.5-0.7 \times 0.5-1.2 \mu \mathrm{m})$ are borne in spiral chains with two to three turns. Spore surface smooth. Grows well on modified Bennett's agar. Tweens 40 and 60 are degraded. Does not use methanol or propanol as a sole carbon source (at $1 \%, \mathrm{v} / \mathrm{v}), \alpha$-Alanine, L-glycine, $\mathrm{L}-$ histidine, L-isoleucine, DL-methionine, L-ornithine, L-phenylalanine, L-threonine and L-valine are used as sole nitrogen sources (at $1 \%, \mathrm{w} / \mathrm{v}$ ). Sensitive to doxycycline hydrochloride, erythromycin, gentamicin sulphate, kanamycin sulphate, neomycin sulphate, oleandomycin phosphate, rifampicin, streptomycin sulphate, tetracycline hydrochloride and tobramycin sulphate $\left(8 \mu \mathrm{g} \mathrm{ml} \mathrm{m}^{-1}\right)$, cephaloridine hydrochloride $\left(32 \mu \mathrm{g} \mathrm{ml}^{-1}\right)$, chlortetracycline hydrochloride $\left(64 \mu \mathrm{g} \mathrm{ml}{ }^{-1}\right)$, fusidic acid $(16 \mu \mathrm{g}$ $\left.\mathrm{ml}^{-1}\right)$, lincomycin hydrochloride and novobiocin $(4 \mu \mathrm{g}$ $\left.\mathrm{ml}^{-1}\right)$, and penicillin $\mathrm{G}\left(20 \mu \mathrm{g} \mathrm{ml}^{-1}\right)$. Other phenotypic properties are mentioned in the text or in Table 1. The $\mathrm{G}+\mathrm{C}$ content of the DNA of the type strain is $71.2 \mathrm{~mol} \%$. Produces decoyinin and psicofuranine; the latter shows antitumour activity.

The type strain, DSM $41427^{\mathrm{T}}\left(=\mathrm{NRRL} 2666^{\mathrm{T}}\right)$, was isolated from garden soil.

\section{Description of Streptomyces milbemycinicus sp. nov.}

Streptomyces milbemycinicus (mil.be.my.ci'ni.cus. N.L. n. milbemycinum milbemycin, an antibiotic; L. masc. suff. -icus adjectival suffix used with various meanings; N.L. masc. adj. milbemycinicus related to milbemycin, referring to the ability of the organism to produce milbemycin).

The description is based upon data taken from this and from previous studies (Aoki et al., 1976; Haber et al., 1991). Aerial hyphae develop from a finely branched substrate mycelium to form whorls with spirals or loops. Chains of 10-50 warty spores $(0.6-0.9 \times 1.1-1.5 \mu \mathrm{m})$ are formed. Grows well on modified Bennett's agar, Czapek-sucrose, inorganic salts-starch and maltose-tryptose agars, and from 18 to $55{ }^{\circ} \mathrm{C}$. Does not use methanol or propanol as a sole carbon source (at $1 \%, \mathrm{v} / \mathrm{v}$ ) or grow in the presence of $0.1 \%(\mathrm{v} / \mathrm{v})$ phenol. Sensitive to gentamicin sulphate, kanamycin sulphate, neomycin sulphate, streptomycin sulphate and tobramycin sulphate $\left(8 \mu \mathrm{g} \mathrm{ml}^{-1}\right)$, erythromycin, lincomycin hydrochloride, rifampicin and oleandomycin phosphate $\left(32 \mu \mathrm{g} \mathrm{ml}^{-1}\right)$ and doxycycline hydrochloride $\left(4 \mu \mathrm{g} \mathrm{ml}^{-1}\right)$. Other phenotypic properties are mentioned either in the text or in Table 1. The G+C content of the DNA of the type strain is $71 \mathrm{~mol} \%$. Produces milbemycin.
The type strain is DSM $41911^{\mathrm{T}}\left(=\mathrm{NRRL} 5739^{\mathrm{T}}\right)$.

\section{Streptomyces wellingtoniae sp. nov.}

Streptomyces wellingtoniae (wel.ling.to' ni.ae. N.L. fem. gen. $\mathrm{n}$. wellingtoniae of Wellington, named in honour of Elizabeth Wellington for her contributions to streptomycete systematics).

The description is based upon data taken from this and a previous study (Tresner \& Backus, 1956). Smooth spores $(0.5-0.7 \times 0.5-1.2 \mu \mathrm{m})$ borne in loops and spirals with one or two turns. Grows well on modified Bennett's agar. Degrades casein, hypoxanthine and Tweens 40 and 60, but not starch. Does not use methanol or propanol as a sole carbon source (at $1 \%, \mathrm{v} / \mathrm{v}) . \alpha$-Alanine, L-alanine, L-asparagine, L-isoleucine, L-histidine, DL-methionine, Lornithine, L-phenylalanine, L-serine, L-threonine and Lvaline are used as sole nitrogen sources for energy and growth (all at $1 \%, w / v)$. Sensitive to doxycycline hydrochloride, gentamicin sulphate, kanamycin sulphate, neomycin sulphate, streptomycin sulphate and tobramycin sulphate $\left(8 \mu \mathrm{g} \mathrm{ml}^{-1}\right)$ and erythromycin, lincomycin hydrochloride, rifampicin and oleandomycin phosphate $\left(32 \mu \mathrm{g} \mathrm{ml}^{-1}\right)$. Other phenotypic properties are mentioned either in the text or in Table 1 . The $\mathrm{G}+\mathrm{C}$ content of the DNA of the type strain is $72 \mathrm{~mol} \%$.

The type strain is DSM $40632^{\mathrm{T}}\left(=\mathrm{NRRL} B-1503^{\mathrm{T}}\right)$.

\section{Acknowledgements}

Y.K. is grateful to the University of Newcastle for an International Research Scholarship and to the School of Biology for a Research Studentship. The authors are indebted to the ARS Culture Collection, Peoria, IL, USA, and to Dr Ernest Lacey and Mr Stuart Robinson for providing some of the S. hygroscopicus strains used in this study. We thank Dr Jean Euzéby, École Nationale Vétérinaire, Toulouse, France, for his help with the nomenclature and etymology.

\section{References}

Altschul, S. F., Madden, T. L., Schaffer, A. A., Zhang, J., Zhang, Z., Miller, W. \& Lipman, D. J. (1997). Gapped BLAST and PSI-BLAST: a new generation of protein database search programs. Nucleic Acids Res 25, 3389-3402.

Aoki, A., Fukuda, R., Nakayabu, T., Ishibashi, K., Takeichi, C. \& Ishida, M. (1976). Antibiotic substances. US Patent 3,950,360.

Atalan, E., Manfio, G. P., Ward, A. C., Kroppenstedt, R. M. \& Goodfellow, M. (2000). Biosystematic studies on novel streptomycetes from soil. Antonie van Leeuwenhoek 77, 337-353.

Bull, A. T., Stach, J. E. M., Ward, A. C. \& Goodfellow, M. (2005). Marine actinobacteria: perspectives, challenges and future directions. Antonie van Leeuwenhoek 87, 37-42.

De Vos, P. \& Trüper, H. G. (2000). Judicial Commission of the International Committee on Systematic Bacteriology. IXth International (IUMS) Congress of Bacteriology and Applied Microbiology. Minutes of the meetings, 14, 15 and 18 August 1999, Sydney, Australia. Int J Syst Evol Microbiol 50, 2239-2244. 
Dietz, A. \& Mathews, J. (1962). Taxonomy of carbon replication. I. An examination of Streptomyces hygroscopicus. Appl Microbiol 10, 258-263.

Dietz, A. \& Mathews, J. (1969). Scanning electron microscopy of selected members of the Streptomyces hygroscopicus group. Appl Microbiol 18, 694-696.

DSMZ (1998). Catalogue of Strains. Braunschweig: DSMZ.

Duangmal, K., Ward, A. C. \& Goodfellow, M. (2005). Selective isolation of members of the Streptomyces violaceoruber clade from soil. FEMS Microbiol Lett 245, 321-327.

Felsenstein, J. (1981). Evolutionary trees from DNA sequences: a maximum likelihood approach. J Mol Evol 17, 368-376.

Felsenstein, J. (1985). Confidence limits on phylogenies: an approach using the bootstrap. Evolution 39, 783-791.

Felsenstein, J. (1993). PHYLIP (phylogeny inference package) version 3.5c. Department of Genome Sciences, University of Washington, Seattle, USA.

Fitch, W. M. \& Margoliash, E. (1967). Construction of phylogenetic trees: a method based on mutation distances as estimated from cytochrome $c$ sequences is of general applicability. Science 155, 279-284.

Goodfellow, M., Kumar, Y., Labeda, D. P. \& Sembiring, L. (2007). The Streptomyces violaceusniger clade: a home for streptomycetes with rugose ornamented spores. Antonie van Leeuwenhoek 92, 173-197.

Haber, C. L., Heckaman, C. L., Li, G. P., Thompson, D. P., Whaley, H. A. \& Wiley, V. H. (1991). Development of a mechanism of actionbased screen for anthelmintic microbial metabolites with avermectin like activity and isolation of milbemycin-producing Streptomyces strains. Antimicrob Agents Chemother 35, 1811-1817.

Hütter, R. (1967). Systematik der Streptomyceten unter besonderer Berücksiehtung der von ihnen gebildetern Antibiotika. Bibliotheka Mikrobiologica, Fasc. vol. 6. Basel: S. Karger (in German).

Jukes, T. H. \& Cantor, C. R. (1969). Evolution of protein molecules. In Mammalian Protein Metabolism, vol. 3, pp. 21-132. Edited by H. N. Munro. New York: Academic Press.

Kluge, A. G. \& Farris, F. S. (1969). Quantitative phyletics and evolution of anurans. Syst Zool 18, 1-12.

Kumar, Y. \& Goodfellow, M. (2008). Five new members of the Streptomyces violaceusniger $16 \mathrm{~S}$ rRNA gene clade: Streptomyces castelarensis comb. nov., S. himastatinicus sp. nov., S. mordarskii sp. nov., S. rapamycinicus sp. nov. and S. ruanii sp. nov. Int J Syst Evol Microbiol 58, 1369-1378.

Kumar, Y., Aiemsum-ang, P., Ward, A. C. \& Goodfellow, M. (2007). Diversity and geographical distribution of members of the Streptomyces violaceusniger $16 \mathrm{~S}$ rRNA gene clade detected by clade specific PCR primers. FEMS Microbiol Ecol 62, 54-63.

Lanoot, B., Vancanneyt, M., Cleenwerck, I., Wang, L., Li, W., Liu, Z. \& Swings, J. (2002). The search for synonyms among streptomycetes by using SDS-PAGE of whole-cell proteins. Emendation of the species Streptomyces aurantiacus, Streptomyces cacaoi subsp. cacaoi, Streptomyces caeruleus and Streptomyces violaceus. Int J Syst Evol Microbiol 52, 823-829.

Lanoot, B., Vancanneyt, M., Dawyndt, P., Cnockaert, M., Zhang, J., Huang, Y., Liu, Z. \& Swings, J. (2004). BOX-PCR fingerprinting as a powerful tool to reveal synonymous names in the genus Streptomyces. Emended descriptions are proposed for the species Streptomyces cinereorectus, S. fradiae, S. tricolor, S. columbiensis, S. filamentosus, S. vinaceus and S. phaeopurpureus. Syst Appl Microbiol 27, 84-92.

Lanoot, B., Vancanneyt, M., Hoste, B., Vandameulebroecke, K., Cnockaert, M. C., Dawyndt, P., Liu, Z., Huang, Y. \& Swings, J. (2005). Grouping streptomycetes using 16S-ITS RFLP fingerprinting. Res Microbiol 156, 755-762.
Lapage, S. P., Sneath, P. H. A., Lessel, E. F., Skerman, V. B. D., Seeliger, H. P. R. \& Clark, W. A. (editors) (1992). International Code of Nomenclature of Bacteria (1990 Revision). Washington, DC: American Society for Microbiology.

Liu, Z., Shi, Y., Zhang, Y., Zhou, Z., Lu, Z., Li, W., Huang, Y., Rodriguez, C. \& Goodfellow, M. (2005). Classification of Streptomyces griseus (Krainsky 1914) Waksman and Henrici 1948 and related species and the transfer of 'Microstreptospora cinerea' to the genus Streptomyces as Streptomyces yanii sp. nov. Int J Syst Evol Microbiol 55, 1605-1610.

Manfio, G. P., Zakrzewska-Czerwinska, J., Atalan, E. \& Goodfellow, M. (1995). Towards minimal standards for the description of Streptomyces species. Biotekhnologia 7-8, 242-283.

Manfio, G. P., Atalan, E., Zakrzewska-Czerwinska, J., Mordarski, M., Rodriguez, C., Collins, M. D. \& Goodfellow, M. (2003). Classification of novel soil streptomycetes as Streptomyces aureus sp. nov., Streptomyces laceyi sp. nov. and Streptomyces sanglieri sp. nov. Antonie van Leeuwenhoek 83, 245-255.

Ohmori, T., Okanishi, M. \& Kawaguchi, H. (1962). Glebomycin, a new member of the steptomycin class. III. Taxonomic studies on Strain $\mathrm{N}^{\mathrm{o}}$ 12096, producer of glebomycin. J Antibiot A 15, 21-27.

Saitou, N. \& Nei, M. (1987). The neighbor-joining method: a new method for reconstructing phylogenetic trees. Mol Biol Evol 4, 406428.

Sembiring, L., Ward, A. C. \& Goodfellow, M. (2000). Selective isolation and characterisation of members of the Streptomyces violaceusniger clade associated with the roots of Paraserianthes falcataria. Antonie van Leeuwenhoek 78, 353-366.

Shirling, E. B. \& Gottlieb, D. (1966). Methods for characterization of Streptomyces species. Int J Syst Bacteriol 16, 313-340.

Staneck, J. L. \& Roberts, G. D. (1974). Simplified approach to identification of aerobic actinomycetes by thin-layer chromatography. Appl Microbiol 28, 226-231.

Strohl, W. (2004). Antimicrobials. In Microbial Diversity and Bioprospecting, pp. 288-313. Edited by A. T. Bull. Washington, DC: American Society for Microbiology.

Sun, W., Huang, Y., Zhang, Y.-Q. \& Liu, Z.-H. (2007). Streptomyces emeiensis sp. nov., a novel streptomycete from soil in China. Int J Syst Evol Microbiol 57, 1635-1639.

Tresner, H. D. \& Backus, E. J. (1956). A broadened concept of the characteristics of Streptomyces hygroscopicus. Appl Microbiol 4, 243250.

Vavra, J. J., Dietz, A., Churchill, B. W., Shiminoff, P. \& Koepsell, H. J. (1959). Psicofuranine. III. Production and biological studies. Antibiot Chemother 9, 427-431.

Ward, A. C. \& Goodfellow, M. (2004). Phylogeny and functionality: taxonomy as a roadmap to genes. In Microbial Diversity and Bioprospecting, pp. 288-313. Edited by A. T. Bull. Washington, DC: American Society for Microbiology.

Williams, S. T., Goodfellow, M., Alderson, G., Wellington, E. M. H., Sneath, P. H. A. \& Sackin, M. J. (1983). Numerical classification of Streptomyces and related genera. J Gen Microbiol 129, 1743-1813.

Xu, C., Wang, L., Cui, Q., Huang, Y., Liu, Z., Zhang, G. \& Goodfellow, M. (2006). Novel neutrotolerant acidophilic Streptomyces species isolated from a soil in China: Streptomyces guanduensis sp. nov., Streptomyces paucisporeus sp. nov., Streptomyces rubidus sp. nov. and Streptomyces yanglinensis sp. nov. Int J Syst Evol Microbiol 56, 1109-1115.

Yao, R. C. \& Hamill, R. L. (1993). Polyether antibiotic. US Patent $5,242,814$.

Yüntsen, H., Ohkuma, K., Ishii, Y. \& Yonehara, H. (1956). Studies on angustmycin. J Antibiot (Tokyo) 9, 195-201. 